\title{
"Development of risk-oriented approach to assessing the client during financial monitoring on the real estate market"
}

\begin{tabular}{|c|c|}
\hline \multirow{3}{*}{ AUTHORS } & Nataliya Vnukova iD http://orcid.org/0000-0002-1354-4838 \\
\hline & R http://www.researcherid.com/rid/T-9097-2018 \\
\hline & Daria Davidenko id https://orcid.org/0000-0001-9124-9511 \\
\hline ARTICLE INFO & $\begin{array}{l}\text { Nataliya Vnukova and Daria Davidenko (2019). Development of risk-oriented } \\
\text { approach to assessing the client during financial monitoring on the real estate } \\
\text { market. Development Management, 17(1),63-72. doi:10.21511/dm.5(1).2019.06 }\end{array}$ \\
\hline DOI & http://dx.doi.org/10.21511/dm.5(1).2019.06 \\
\hline RELEASED ON & Wednesday, 24 July 2019 \\
\hline RECEIVED ON & Tuesday, 29 January 2019 \\
\hline \multirow[t]{2}{*}{ ACCEPTED ON } & Wednesday, 08 May 2019 \\
\hline & $(\mathrm{cc}) \mathrm{EY}_{\mathrm{EY}}$ \\
\hline LICENSE & $\begin{array}{l}\text { This work is licensed under a Creative Commons Attribution } 4.0 \text { International } \\
\text { License }\end{array}$ \\
\hline JOURNAL & "Development Management" \\
\hline ISSN PRINT & $2413-9610$ \\
\hline ISSN ONLINE & $2663-2365$ \\
\hline PUBLISHER & LLC "Consulting Publishing Company "Business Perspectives" \\
\hline FOUNDER & Simon Kuznets Kharkiv National University of Economics \\
\hline
\end{tabular}

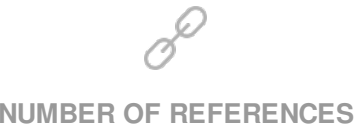

23
NUMBER OF FIGURES

2
NUMBER OF TABLES

3

(C) The author(s) 2022. This publication is an open access article. 


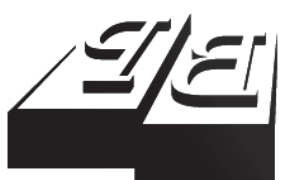

BUSINESS PERSPECTIVES

Publisher

LLC "CPC "Business Perspectives" Hryhorii Skovoroda lane, 10, Sumy, 40022, Ukraine www.businessperspectives.org

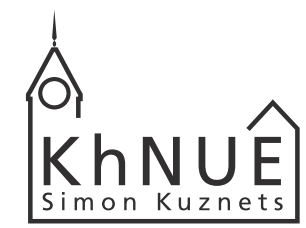

\section{S. KUZNETS KHNUE}

Founder

Simon Kuznets Kharkiv National University of Economics, Nauky avenue, 9-A, Kharkiv, 61166,

Ukraine

http://www.hneu.edu.ua/

Received on: 29th of

January, 2019

Accepted on: 08th of

May, 2019

(c) Nataliya Vnukova,

Daria Davudenko, 2019

Nataliya Vnukova, Doctor of Economics, Professor, Head of the Department of Financial Services Management of the Simon Kuznets Kharkiv National University of Economics, Ukraine

Daria Davudenko, Candidate of Science (Economics), lecturer of the Department of Financial Services Management of the Simon Kuznets Kharkiv National University of Economics, Ukraine

\section{(ㄷ) (i)}

This is an Open Access article, distributed under the terms of the Creative Commons Attribution 4.0 International license, which permits unrestricted re-use, distribution, and reproduction in any medium, provided the original work is properly cited.
Nataliya Vnukova (Ukraine), Daria Davidenko (Ukraine)

\section{DEVELOPMENT OF RISK-ORIENTED APPROACH TO ASSESSING THE CLIENT DURING FINANCIAL MONITORING ON THE REAL ESTATE MARKET}

\begin{abstract}
The system of financial monitoring establishes specifically designated entities on the real estate market. The assessment of a client's risk of money laundering when entering into agreements in this market is a complex task and requires the development of new tools for implementing the risk-oriented approach, which is a priority in accordance with international standards in the financial monitoring system. The purpose of the study is to develop a risk-oriented approach to assessing the client and to develop practical recommendations for determining its level of risk in financial monitoring in the real estate market. To achieve a specific goal, a system of general scientific and special research methods, expert rankings and optimization modeling are used. On the basis of Methodical materials on financial monitoring issues for business entities, which provide services in the course of real estate purchase and sale operations, the points of client's correspondence to high risk, which corresponds to the concept of developing a risk-oriented approach based on the main criteria of client risk assessment: geographic location of the state, client type and business relations. Taking into account the complexity of such assessment and the necessity of operative decision-making, a risk assessment rating (cost) scale has been developed for an integrated automated determination of a client's risk level and an assessment of high-risk clients in the Decision Making Helper decision-making support system software on specific examples of legislation violations concerning the financial monitoring on the real estate market. The feasibility of implementing a new risk-oriented approach to assessing high-risk clients has been proved by automating the process of determining its level to reduce the time to decide on prevention and counteraction to the legalization of incomes and money laundering.
\end{abstract}

Keywords

JEL Classification risk, real estate, Decision Making Helper, client risk level, money laundering, financial services market

R31, L85
Н.М. Внукова (Україна), Д.О. Давиденко (Україна)

\section{РОЗВИТОК РИЗИКО-ОРІЕНТОВАНОГО ПІДХОДУ ДО ОЦІКИ КЛІЄНТА ПРИ ФІНАНСОВОМУ МОНІТОРИНГУ НА РИНКУ НЕРУХОМОГО МАЙНА}

\begin{abstract}
Анотація
Система фінансового моніторингу встановлює спеціально визначених суб’єктів на ринку нерухомого майна. Оцінка ризику клієнта щодо відмивання коштів при укладанні угод на цьому ринку є складним завданням і потребує розробки нових інструментів впровадження ризико-орієнтованого підходу, який $є$ пріоритетним відповідно до міжнародних стандартів в системі фінансового моніторингу. Метою дослідження $є$ розвиток ризико-орієнтованого підходу до оцінки клієнта та розробка практичних рекомендацій щодо визначення рівня його ризику при фінансовому моніторингу на ринку нерухомого майна. Для досягнення визначеної мети використано систему загальнонаукових і спеціальних методів дослідження, експертне ранжування та оптимізаційне моделювання. На основі Методичних матеріалів з питань фінансового моніторингу для суб’єктів підприємницької діяльності, які надають послуги під час здійснення операцій з купівлі-продажу нерухомого майна, виділено пункти відповідності клієнта високому ризику, що відповідає концепції розвитку ризико-орієнтованого підходу за основними критеріями оцінки ризику клієнта: географічне розташування держави, тип клієнта та ділові відносини. Враховуючи складність такого оцінювання та необхідність оперативного прийняття рішень, для інтегрованого автоматизованого визначення рівня
\end{abstract}


ризику клієнта розроблено шкалу рейтингування (вартості) критеріїв ризику та проведено оцінку клієнтів з високим ризиком у програмному продукті системи підтримки ухвалення рішень Decision Making Helper на конкретних прикладах порушень законодавства з питань фінансового моніторингу на ринку нерухомого майна. Доведено доцільність запровадження нового інструменту ризико-орієнтованого підходу до оцінки клієнтів з високим ризиком через автоматизацію процесу визначення його рівня для скорочення часу на ухвалення рішення щодо запобігання та протидії легалізації доходів і відмивання коштів.
Ключові слова
Класифікація JEL
ризик, нерухомість, Decision Making Helper, рівень ризику клієнта, фінансовий моніторинг, відмивання коштів, ринок фінансових послуг
R31, L85

\section{ВСТУП}

Операції з управління майном для фінансування об’єктів будівництва та/або здійснення операцій 3 нерухомістю віднесені до переліку фінансових послуг 2013 року [18], що є розширенням сфери контролю за фінансовими послугами на ринку нерухомості, визначеної іншими законами $[18,19,20]$. Отже, Державна служба фінансового моніторингу (далі - Держфінмоніторинг) розширила діапазон своєї діяльності та здійснює перевірки спеціально визначених суб’єктів первинного фінансового моніторингу (далі - СВСПФМ) на ринку нерухомості у встановленому порядку.

Порядок здійснення цих перевірок на ринку житлової нерухомості перебуває на стадії розвитку, додаткового методичного забезпечення та регулювання 2018 року з боку Держфінмоніторингу [1, $14,15,16]$. Особливої уваги потребує процес визначення рівня ризику клієнта, що потрапляє у сферу діяльності СВСПФМ, зокрема, на ринку нерухомості для запровадження ризик-орієнтованого підходу в системі фінансового моніторингу. На цей час в Україні перевірки спрямовані здебільшого на виявлення порушень, а не на їх запобігання у сфері фінансового моніторингу, до того ж існує процедура блокування угод, пов’язаних із відмиванням коштів $[20,10]$, тому вчасне та оперативне виявлення клієнтів з високим ризиком $€$ актуальним завданням СВСПФМ.

Так як оцінка ризику клієнта $є$ важливою складовою діяльності СВСПФМ у системі фінансового

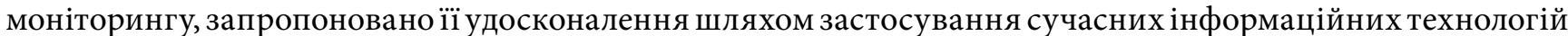
(системи підтримки прийняття рішень Decision Making Helper), що сприятиме своєчасному виявленню порушень, пов’язаних із відмиванням коштів і легалізацією доходів, одержаних злочинним шляхом. Це знизить витрати часу на обробку інформації щодо ідентифікації клієнтів для попередження сумнівних операцій.

\section{1. ЛІТЕРАТУРНИЙ ОГЛЯА}

Проблему ефективності фінансового моніторингу та окремі питання розвитку системи оцінювання дій клієнта в Україні та за тї межами досліджували такі науковці, як: Коттке [11], Андрійченко [2], Базелюк [3], Буткевич [4], Глущенко та співавтори [9], Дмитров та співавтори [6], Єгоричева [7], Користін та співавтори [23], Ксу (Xue) та Занг (Zhang) [22] та ін.

Наприклад, Єгоричева [7] детально розглядала питання організації фінансового моніторингу в банку, а саме стверджувала, що заходи щодо запобігання легалізації доходів, одержаних злочинним шляхом, повинні розглядатися як невід’єна частина глобальної політики боротьби зі злочинністю, яка руйнує економіку та суспільство у цілому. В $\dddot{̈}$ працях наголошується, що привабливість інститутів фінансового сектору для здійснення відмивання коштів та фінансування тероризму обумовлює їх особливу роль у протидії цим загрозливим явищам.

Питання адміністративного права та процесу фінансового моніторингу на ринку розглядає в своїх працях Користін [23] стверджуючи, що найвідоміші способи, які використовуються під час інтеграції

- це продаж нерухомості; недостовірність цін зовнішньоторговельних операцій; угоди із заниженням 
ціни; трансферпрайсінг; використання банківських рахунків іноземної чи спільної фірми; депонування готівки на банківський рахунок фірми; підставні компанії та фіктивні кредити; казино та лотереї; встановлення контролю над іноземними банками.

В свою чергу Буткевич [4] надає перевагу в своїх дослідженнях світовому досвіду відмивання грошей та фінансового моніторингу, а саме розглядає процеси фінансування тероризму в таких країнах як США, Канада, Японія. Він наголошує на демократичних та правових основах діяльності органів державної влади та місцевого самоврядування, що значною мірою впливають на ефективність протидії відмиванню доходів, отриманих злочинним шляхом.

Останнім часом зросла увага міжнародного регулятора (FATF) до результатів оцінки ризику фінансового моніторингу [8] та узагальнення досвіду здійснення фінансового моніторингу на ринку фінансових послуг європейських країн [12].

Однак залишається недостатньо визначеним процес оцінювання клієнта за критеріями Держфінмоніторингу $[14,15,16]$ з огляду запровадження ризико-орієнтованого підходу на ринку нерухомості. Вирішення цього завдання дозволить удосконалити процедуру оцінки ризику клієнта, що задовольнить потреби учасників ринку нерухомості та прискорить реагування СВСПФМ на будь-які можливі порушення законодавства в сфері фінансового моніторингу.

\section{2. МЕТА ДОСЛІДЖЕННЯ}

Метою дослідження є розвиток ризико-орієнтованого підходу до оцінки клієнта та розробка практичних рекомендацій щодо визначення рівня його ризику при фінансовому моніторингу на ринку нерухомого майна.

\section{3. МЕТОДИ ДОСЛІДЖЕННЯ}

Теоретичною основою дослідження є праці сучасних науковців та законодавство України у сфері фінансового моніторингу. Для досягнення визначеної мети використано систему загальнонаукових і спеціальних методів дослідження: теоретичне узагальнення, порівняння (для уточнення критеріїв оцінки ризику клієнта); системний аналіз, формалізація (для інтерпретації результатів оцінки ризику клієнта для фінансового моніторингу); експертне ранжування (для оцінювання важливості критеріїв вибору в СППР Decision Making Helper); оптимізаційне моделювання (для визначення рівня ризику клієнта); графічний метод (для унаочнення емпіричних даних і схематичного викладення основних теоретичних і практичних положень).

\section{4. РЕЗУЛЬТАТИ}

Держфінмоніторинг підготував Звіт за результатами секторальної оцінки ризиків використання ринку нерухомості для легалізації (відмивання) доходів, одержаних злочинним шляхом і фінансування тероризму (2018) [1], а також низку методичних рекомендацій до проведення фінансового моніторингу на ринку нерухомості $[14,15,16]$. Відповідно до Методичних матеріалів з питань фінансового моніторингу для суб'єктів підприємницької діяльності, які надають посередницькі послуги під час здійснення операцій з купівлі-продажу нерухомого майна [14], що надає Держфінмоніторинг, оцінка ризику клієнта здійснюється за трьома основними критеріями: за типом клієнта (статус), за географічним розташуванням держави реєстрації клієнта, за діловими відносинами (видом товарів та послуг). Кожний з трьох критеріїв має реальний зміст - пункти, яким мають відповідати клієнти СВСПФМ. Для формалізації процесів, пов’язаних із визначенням рівня ризику клієнтів для запровадження ризик-орієнтованого підходу, автори узагальнили зміст критеріїв за Методичними матеріалами [14] та виділили пункти відповідності клієнта високому ризику (Таблиця 1). 
Таблиця 1. Зміст критеріїв оцінки ризику клієнта спеціально-визначеного суб’єкта первинного фінансового моніторингу на ринку нерухомості

Джерело: розроблено авторами на основі [14], виконали сортування критеріїв ризику і виділили пункти відповідності високому ризику клієнта при фінансовому

\begin{tabular}{c|ccc}
\hline $\begin{array}{c}\text { Критерій } \\
\text { ризику }\end{array}$ & 3міст критеріїв ризику для оцінки клієнта \\
\hline
\end{tabular}

$3 a$

географічним

держави

клієнта розташування

Віднесення держави до країн з неналежним виконанням вимог до фінансового моніторингу.

Підтримання державою терористичної діяльності або порушення національного законодавства або міжнародних організацій, зокрема ООН.

Внесення держави до реєстру офшорних зон.

За вимогами FATF держава має суттєві недоліки у сфері протидії легалізації (відмиванню) доходів чи фрінансуванню тероризму.

Здійснення клієнтом терористичної діяльності або застосування до нього міжнародних санкцій за списком Держфінмоніторингу.

Віднесення клієнта до публічних діячів або його близьких осіб чи пов'язаних з ним осіб.

Приналежність клієнта до неприбуткової організації.

Встановлення кореспондентських стосунків з клієнтом як іноземною фінансовою установою.

Проведення клієнтом фінансових операцій на ринку фрінансових послуг без відповідності його стану та/або змісту практики.

За типом Наявність у клієнта складної структури власності або він є трастом чи фондом довірчого управління.

Надання клієнтом фінансових послуг з обміну валют та/або переказу грошових коштів.

Здійснення клієнтом діяльності, що пов'язана з азартними іграми, зокрема, лотереями

Виконання клієнтом операцій з реалізації зброї або її виробництва.

Акціонерне товариство клієнта-нерезидента здійснило випуск акцій на пред'явника.

Сумнівне місцезнаходження клієнта, не подання протягом двох років звітності, що стало відомо з відкритих джерел.

Складний або сумнівний характер фінансової операції, що не відповідає меті здійснюваних дій.

Багатократне проведення операцій з пороговим рівнем, що тягне виникнення сумнівів з уникнення ідентифікації та процедур фрінансового моніторингу.

Регулярні операції з готівкою, яка надходить від інших клієнтів або третіх осіб безготівково.

Постійні касові операції з готівкою із перевищенням залишку на рахунку клієнта.

Без відсутності міжнародного контракту здійснення фінансових операцій з переказу коштів за кордон.

За діловими відносинами (видом товарів та послуг)
Систематичні операції з повернення, одержання, надання позик, фрінансової допомоги, кредитів та нових запозичень.

Фінансові операції через посередника, який не має встановленого прямого (особистого) контакту з клієнтом.

Виконання операцій з реалізації, купівлі/продажу або відступлення права вимоги коштів.

Одержання постійного прибутку або постійних збитків клієнтом через систематичне укладення ним строкових угод або застосування операцій з похідними фінансовими інструментами без поставки базового активу або здійснення спеціальних операцій з одним або кількома контрагентами.

Можливе порушення встановленої законодавством граничної суми розрахунку готівкою через дії клієнта з її перевищення.

Підозри фрінансового моніторингу при надання дистанційних послуг.
Пункт 1-3 ст. 2 [14]

Пункти $1,2,4$ ст. $2[14]$ 
Як видно з Таблиці 1, зміст критеріїв досить масштабний, а високий ризик клієнта визначається за наявністю конкретних пунктів. Також при визначенні групи ризику клієнта варто зауважити, якщо клієнт підпадає хоча 6 під один із критеріїв ризику, тоді рівень ризику такого клієнта не може визначатися як «низький». Ще одним важливим аспектом $є$ сутнісна характеристика пунктів - вона не $\epsilon$ винятковою, але найбільш поширеною. Крім того, для відповідальних за фінансовий моніторинг важливим $€$ не тільки сама оцінка ризику, а ухвалення рішення в короткий термін часу щодо подальшого обслуговування клієнта. Зважаючи на те, що процес оцінки з огляду на кількість пунктів у кожному 3 критеріїв є складним, потребує обробки різної інформації, що вимагає як часових, так й інших ресурсів, яких не вистачає суб’єктам підприємницької діяльності, запропоновано автоматизувати цей процес і застосувати програму Decision Making Helper [5], що є системою підтримки прийняття рішень (СППР) або продуктом, що дозволяє автоматизувати визначення рівня ризику клієнта за оцінкою експертів, якими $є$ працівники СВСПФМ, які відповідно до закону [20] надають посередницькі послуги під час здійснення операцій з купівлі-продажу нерухомого майна.

При виборі цього програмного продукту здійснено порівняння з іншими системами підтримки рішень, що дають змогу виконувати оптимізаційні завдання різного характеру, але їх застосування є ускладненим і не дозволяє досягти мети для поставленого завдання з фінансового моніторингу на ринку нерухомості. Розглянута програма SIMBA DSS [17] дозволяє виконати вибір клієнта з високим рівнем ризику, але для цього користувачу потрібно ввести не лише набір критеріїв, а і їх класифікувати, що є додатковим завданням для працівників СВСПФМ, крім того, ця дія вже зрегульована Держфінмоніторингом. Програма Decision Making Helper не потребує класифікації критеріїв, оскільки вирішує це завдання через вагові коефіцієнти, що допускає оперативність внесення змін у процедуру оцінювання.

Інша програма СППР «Вибір» [13] дозволяє структурувати критерії та оцінити альтернативи, а також ïx проранжувати на основі методу аналізу ієрархій Сааті. Обмеженість практичного застосування цього програмного продукту полягає в інтерпретації результатів, які представлені у вигляді сітки зі взаємопов’язаними елементами (чим більше критеріїв, тим більша сітка). Подібна інтерпретація не $\epsilon$ наочною та не має належної практичної цінності, на відміну від гістограм, що є результуючими в Decision Making Helper.

Крім того, досвід застосування цього програмного продукту з метою вирішення як навчальних, так i підприємницьких завдань з вибору кращої альтернативи $є$ позитивним. Автори розробили алгоритм вибору найкращого об'єкта інвестування інвестора на ринку житлової нерухомості на основі подібної СППР, що засвідчено охоронним документом Державної служби інтелектуальної власності України [21] та впроваджено в діяльність посередників під час здійснення операцій з купівлі-продажу нерухомого майна для підготовки прийняття клієнтських рішень, отже, розширення напрямів застосування програми Decision Making Helper на ринку нерухомості може бути позитивно сприйнято СВСПФМ та мати практичну цінність з урахуванням необхідності оперативного реагування на нові вимоги Держфінмоніторингу $[15,16]$.

Для вирішення поставленого завдання автори запропонували використати програму Decision Making Helper [5] для визначення рівня ризику клієнта для фінансового моніторингу. Для цього розробили шкалу рейтингування критеріїв оцінки ризику клієнта (Таблиця 1) відповідно до вимог програми. Для внесення оцінок в програму потрібно визначити рівень важливості критеріїв для кожного клієнта за внесеною необхідною рейтинговою оцінкою. Запропоновано використати від (-5) «низький рівень» до (+5) «високий рівень», 0 - нейтральний рівень. Загальна кількість оцінок, яка в представленому діапазоні становить 11, що повністю відповідає кількості пунктів за другим та третім критеріями (Таблиця 1). Щодо першого критерію, який має 4 пункти, то його співвіднесено за 11-бальною шкалою (здійснено за пропорцією). 3 урахуванням наведених критеріїв (Таблиця 1) розроблено шкалу рейтингування (вартості) критеріїв оцінки ризику клієнта в системі фінансового моніторингу на ринку нерухомості за вимогами Decision Making Helper, що представлена в Таблиця 2. Це необхідно було здійснити для узгодження групи критеріїв ризику, кількісного складу критеріїв та їх ваги. 
Таблиця 2. Шкала рейтингування критеріїв оцінки ризику клієнта для внесення в програму Decision Making Helper

Джерело: розроблено авторами

\begin{tabular}{|c|c|c|}
\hline Критерій оцінки ризику клієнта & Пункти критеріїв (кількість) & $\begin{array}{l}\text { Оцінка в програмі Decision Making } \\
\text { Helper }\end{array}$ \\
\hline \multirow{5}{*}{$\begin{array}{l}\text { За географічним розташуванням } \\
\text { держави клієнта }\end{array}$} & 4 & Або +5, або +4 \\
\hline & 3 & +3 \\
\hline & 2 & Або +1, або +2 \\
\hline & 1 & Від -5 до -1 \\
\hline & 0 & 0 \\
\hline \multirow{3}{*}{ За типом клієнта } & $7-11$ & Від +1 до +5 \\
\hline & 6 & Від -5 до -1 \\
\hline & $1-5$ & $0 /-1$ \\
\hline \multirow{3}{*}{$\begin{array}{l}\text { За діловими відносинами (видом товарів } \\
\text { та послуг) }\end{array}$} & $7-11$ & Від +1 до +5 \\
\hline & 6 & Від -5 до -1 \\
\hline & $1-5$ & $0 /-1$ \\
\hline
\end{tabular}

Як видно з Таблиці 2, чим більша кількість пунктів за різними критеріями стосуються конкретного клієнта, тим вище бальна оцінка, що виставляється працівником СВСПФМ. Отже, шляхом середньозваженого попарного порівняння (методу, що закладений у програмне забезпечення Decision Making Helper для автоматизації процесу вибору найбільш ризикового клієнта) визначається клієнт, що отримує найбільшу кількість балів - цей клієнт віднесений до групи з високим ризиком.

Програма СППР Decision Making Helper розраховує автоматично значення рішення для кожного клієнта в процентах від (-100\%) до (+100\%) та у висловах «незадовільно / достатньо незадовільно / нейтрально / достатньо позитивно / позитивно». Автори здійснили за аналогію (відповідністю) опис результатів оцінки в програмі Decision Making Helper щодо оцінки ризику клієнта для цілей фінансового моніторингу на ринку нерухомого майна та отримано результати, що представлені в Таблиці 3.

Таблиця 3. Відповідність результатів оцінки ризику клієнта для фінансового моніторингу в програмі СППР Decision Making Helper

Джерело: розроблено авторами

\begin{tabular}{l|l}
\hline \multicolumn{1}{c}{ Результати в програмі } & Рівень ризику клієнта \\
\hline Незадовільно & Високий рівень \\
Достатньо незадовільно & Сисокий рівень \\
\hline Нейтрально & Низький рівень \\
\hline Достатньо позитивно & Низький рівень \\
\hline Позитивно & \\
\hline
\end{tabular}

Як видно з Таблиці 3, процес інтерпретації (відповідності) результатів $\epsilon$ протилежним щодо результатів, отриманих в програмі, що пов'язано перш за все, із конкретним завданням, що поставлено - це визначення клієнта з найвищим ризиком, а отже, це більш тяжіє до негативної оцінки щодо вибору суб’єктів.

Для перевірки розробленого підходу до застосування програми Decision Making Helper для оцінки ризику клієнта в системі фінансового моніторингу розглянуто конкретних клієнтів на ринку нерухомого майна, що наведені у Звіті за результатами секторальної оцінки ризиків використання ринку нерухомості для легалізації (відмивання) доходів, одержаних злочинним шляхом і фінансування тероризму [1], стосовно яких були застосовані заходи впливу, отже, є клієнтами з високим ризиком.

Приклад 1 (клієнт 1). Державний реєстратор оформив договір купівлі-продажу майна за фіктивними документами, що надала особа, яка в такий спосіб незаконно отримала у власність квартиру. 
Приклад 2 (клієнт 2). У місті Києві в квітні 2018 року затримано особу, що під час продажу квартири мала два паспорти із різними даними та намагалась двічі здійснити реалізацію нерухомого майна.

Приклад 3 (клієнт 3). Особа, що є національним публічним діячем, перетнула кордон України, задекларувавши 274,4 тис грн та 51 тис дол США. За даними митних органів іноземної країни особа задекларувала 162,7 тис євро для купівлі нерухомості в цій країні, що в 3 рази перевищує суму, вказану в українській декларації.

Зазначені клієнти є фактично виявленими випадками порушення законодавства 3 фінансового моніторингу, що демонструють їх виявлення суб’єктом державного фінансового моніторингу вже після вчинення злочину, а не завчасно. Таким чином, зроблено припущення, чи дозволить розроблений ризико-орієнтований підхід запобігти порушенням законодавства щодо встановлення рівня ризику таких клієнтів (див. Таблиці 1, 2, 3). Результати розрахунків за програмою Decision Making Helper наведено на Рисунку 1.

Як видно з Рисунка 1, чим більшій кількості пунктів відповідає клієнт, тим менша його оцінка в програмі і тим більш рівень ризику він має. Так, клієнт 1 за критерієм тип клієнта отримав бал «-1», що відповідає 4 пунктам вимог Держфінмоніторингу [14] (див. Таблицю 1). Аналогічно здійснено оцінювання за іншими клієнтами. Програма Decision Making Helper автоматично визначає рівень ризику за внесеними даними, що наведено на Рисунку 2.

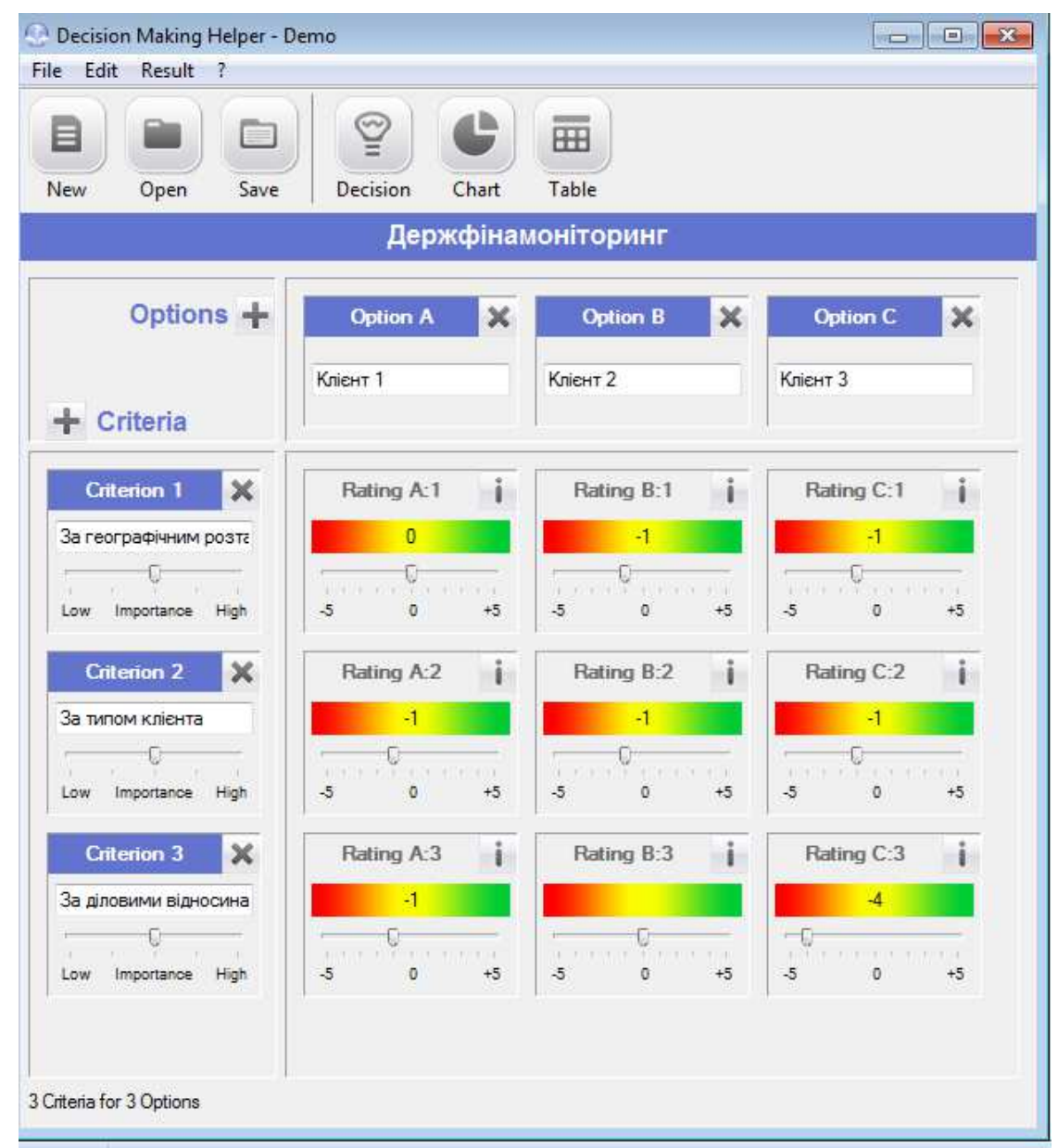

Рисунок 1. Оцінки клієнтів за запропонованим підходом визначення рівня їх ризику 


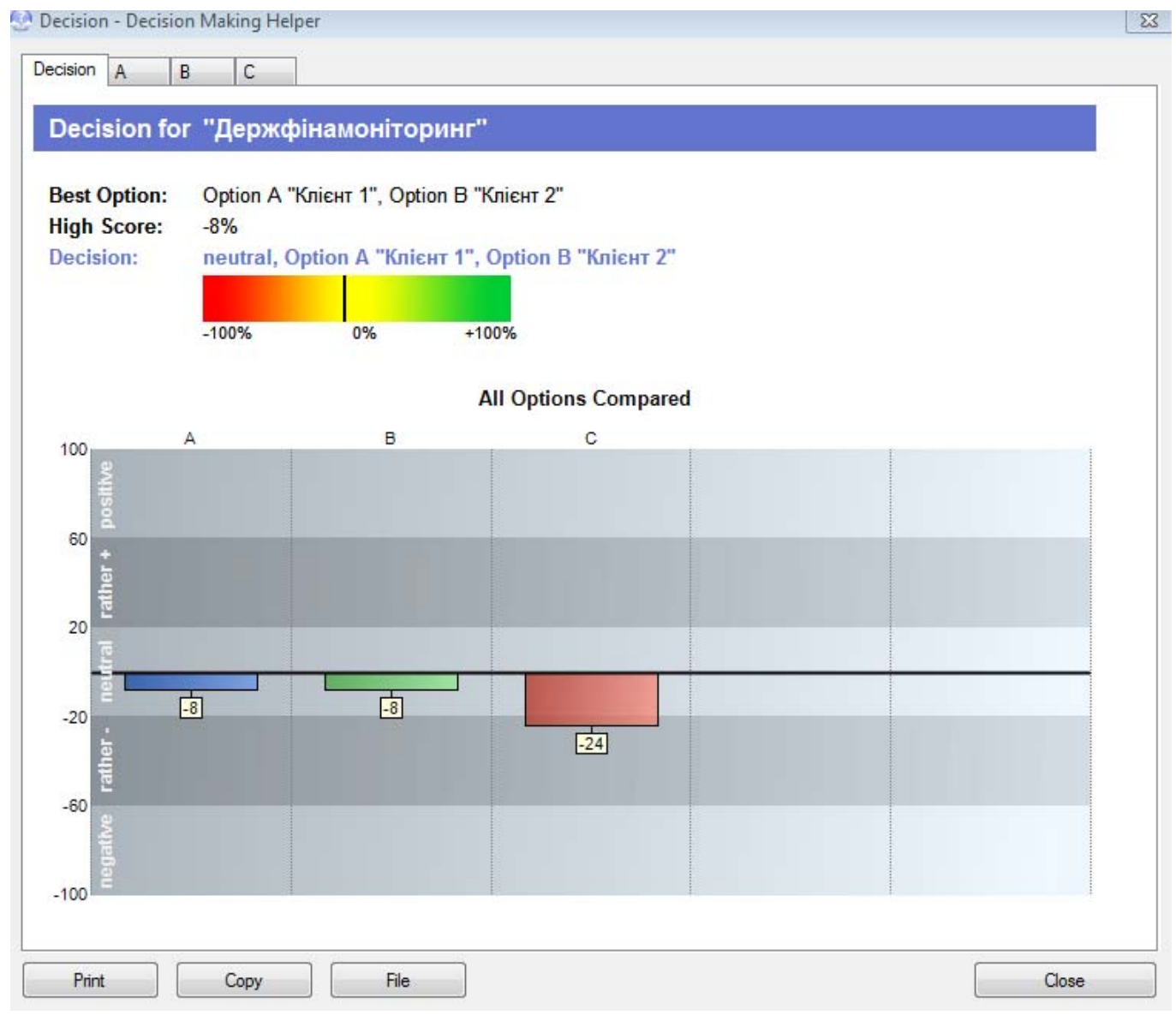

Рисунок 2. Результати оцінки рівня ризику клієнтів

Як видно з Рисунка 2, перші два клієнти віднесені до нейтрального рівня в програмі Decision Making Helper. Вони отримали оцінки згідно з Таблиці 3 щодо середнього рівня ризику. Отже, підлягають додатковому контролю, що могло 6 попередити злочин, який передував відмиванню коштів. Найгіршим виявився клієнт 3 - у програмі в нього незадовільний рівень, що відповідає групі клієнтів з високим ризиком. Якщо детально розглянути пункти відповідності, клієнт є публічним діячем, проводить фінансову операцію, що не відповідає його статусу та є сумнівною, перемішує великі суми готівкових коштів за кордон. Такий клієнт дійсно має бути віднесений до групи з високим ризиком, що підтверджує отримані в програмі результати. Крім того, оцінювання має кількісний вимір, що дає додаткову інформацію щодо рівня ризику у групі високого ризику, отже, акцентує увагу СВСПФМ на необхідності проведення додаткового контролю і додає підстав до можливого блокування сумнівних операцій.

\section{ВИСНОВКИ}

Сучасні вимоги Держфінмоніторингу до оцінки ризику клієнтів на ринку нерухомості потребують додаткового методичного супроводження для посилення заходів щодо запобігання та протидії легалізації (відмивання) доходів. Подальший розвиток ризико-орієнтованого підходу до оцінки клієнта в системі фінансового моніторингу та його запровадження для спеціально визначених суб'єктів первинного фінансового моніторингу полягає у використанні нових інформаційних технологій для прискорення процесу оцінки та підвищення його достовірності через кількісний вимір якісної інформації. 
Запропонований ризико-орієнтований підхід з оцінки клієнта при фінансовому моніторингу на ринку нерухомості з використанням програми Decision Making Helper побудований на формалізації чинних вимог Держфінмоніторингу для практичного їх застосування в процесі визначення рівня ризику клієнта в системі фінансового моніторингу.

Такий підхід апробований на конкретних прикладах порушень у системі фінансового моніторингу і довів свою придатність для використання при оцінці ризику клієнта. Має додаткові переваги щодо економії часу та зниження витрат інших ресурсів СВСПФМ. Він $є$ універсальним і може бути застосовний для інших суб'єктів при додатковій доробці шкал рейтингування критеріїв оцінки ризику клієнтів. Побічною перевагою є можливість своєчасного реагування на зміну критеріїв оцінки або розширення (скорочення) їх переліку, тому що програма Decision Making Helper дозволяє вносити будь-які зміни та наочно демонструвати результати, її застосування є виправданим та альтернативними способом оцінки рівня ризику клієнтів.

Розвинутий ризико-орієнтований підхід має сприяти суб’єктам підприємницької діяльності, які надають посередницькі послуги під час здійснення операцій з купівлі-продажу нерухомого майна, посиленню контролю за ними та виявленню клієнтів з високим ризиком потенційного «відмивання» коштів на стадії укладання угод.

\section{СПИСОК ЛІТЕРАТУРИ}

1. Academy for Financial Monitoring (2018). Звіт за результатами секторальної оцінки ризиків використання ринку нерухомості для легалізаціі (відмивання) доходів, одержаних злочинним иляхом і бінансування тероризму [Zvit za rezultatamy sektoralnoi о sinky ryzykiv vykorystannia rynku nerukhomosti dlia lehalizatsii (vidmyvannia) dokhodiv, oderzhanykh zlochynnym shliakhom i finansuvannia teroryzmu] (110 p.). Retrieved from http://finmonitoring.in.ua/wp-content/uploads/2018/11/sektoralna-neruxomist_21_11_2018.pdf

2. Andriichenko, Zh. O. (2014). Фінансовий моніторинг в системі управління ризиками ринків фінансових послуг [Finansovyi топіtorynh u systemi upravlinnia ryzykamy rynkiv finansovykh posluh]. In Vnukova, N. M. (Ed.). Rozvytok systemy upravlinnia ryzykamy rynkiv finansovykh posluh (pp. 140-150). Kharkiv: Ekskliuzyv. Retrieved from https://bitly.su/OeMj

3. Bazeliuk, A. V. (1998). Тіньова економіка в Украӥні [Tinova ekonomika v Ukraini]. Kyiv: NDEI Minekonomiky Ukrainy.

4. Butkevych, S. A. (2010). Фінансовий моніторинг в Україні [Finansovyi monitorynh v Ukraini: orhanizatsiino-pravovi aspekty]. Simferopol: Krymnavchpedderzhvydav.

5. Decision Making Helper (n.d.). Prohrama SPPR Decision Making Helper. Retrieved from https://www.infonautics-software.ch/decisionmakinghelper

6. Dmytrov, S. O., Merenkova, O. V., \& Medvid, T. A. (2010). Оцінка та управління ризиком використання послуг для легалізації кримінальних доходів або фінансування тероризму в комериійному банку [Otsinka ta upravlinnia ryzykom vykorystannia posluh dlia lehalizatsii kryminalnykh dokhodiv abo finansuvannia teroryzmu v komertsiinomu banku] (133 p.). Sumy: "UABS NBU”.

7. Egoricheva, S. В. (2016). Ризик-орієнтований нагляд у системі фінансового моніторингу [Rizik-oriєntovanij naglyad u sistemi finansovogo monitoringu]. Naukovij visnik Poltavskogo universitetu ekonomiki i torgivli, 3(75), 126-132.

8. FATF (2018). Guidance for a Risk-Based Approach for the Securities Sector (62 p.). Paris: FATF. Retrieved from www.fatf-gafi.org/publications/fatfrecommendations/documents/rba-securities-sector.html

9. Hlushchenko, O. O., \& Semehen, I. V. (2014). Антилегалізаційний фінансовий моніторинг: ризик-орієнтований підхід [Апtуlehalizatsiinyi finansovyi monitorynh: ryzyk-oriientovanyi pidkhid] (389 p.). Kyiv: UBS NBU. Retrieved from http://finmonitoring.in.ua/wpcontent/uploads/2016/06/afm_risk-oriented.pdf

10. Hlushchenko, O. O., \& Raikhert, K. (2014). Consequences of money lundering of illegal incomes for financial and economic security of Ukraine. Financial and credit activity: problems of theory and practice, 17(2), 115-124. Retrieved from https://doi.org/10.18371/fcaptp. v2i17.37328

11. Kottke, K. (2014). Грязные деньги [Gryaznye dengi]. M: Delo i Servis.

12. Savona, E. U., \& Riccardi, M. (Eds) (2017). Assessing the risk of money laundering in Europe (final report of project IARM). Milano: Transcrime - Università Cattolica del Sacro Cuore. Retrieved from www.transcrime.it/iarm

13. SoftPortal (n.d.). Prohrama SPPR Vubir. Retrieved from https://www.softportal.com/software-7763-sppr-vibor.html

14. State Financial Monitoring Service of Ukraine (2016). Методичні матеріали з питань фінансового моніторингу для суб'єктів підприємницької діяльності, які надають посередницькі послуги під час здійснення операцій з купівлі-продажу нерухомого майна [Metodychnykh materialiv z pytan finansovoho monitorynhu dlia subiektiv pidpryiemnytskoi diialnosti, yaki nadaiut poserednytski posluhy pid chas zdiisnennia operatsii z kupivli-prodazhu nerukhomoho maina] (106 p.). Retrieved from http://www.sdfm.gov.ua/content/file/ Site_docs/2018/20181221/Metod_2_1.pdf 
15. State Financial Monitoring Service of Ukraine (2018). Рекомендації для субєєктів підприємницької діяльності, які надають посередницькі послуги під час здійснення операцій з купівлі-продажу нерухомого майна щодо порядку звітування про підозрілі фінансові операиії на підставі ризик-орієнтованого підходу [Rekomendatsii dlia subiektiv pidpryiemnytskoi diialnosti, yaki nadaiut poserednytski posluhy pid chas zdiisnennia operatsii z kupivli-prodazhu nerukhomoho maina shchodo poriadku zvituvannia pro pidozrili finansovi operatsii na pidstavi ryzyk-oriientovanoho pidkhodu]. Retrieved from http://www.sdfm.gov.ua/content/file/Site docs/2018/20181221/Metod_2_5.pdf

16. State Financial Monitoring Service of Ukraine (2018). Щодо виконання вимог законодавства суб'єктами підприємницької діяльності, які надають посередницькі послуги під час здійснення операції з купівлі-продажу нерухомого майна [Shchodo vykonanпіа vyтоh zakonodavstva subiektamy pidpryiemnytskoi diialnosti, yaki nadaiut poserednytski posluhy pid chas zdiisnennia operatsii z kupivli-prodazhu nerukhomoho maina]. Retrieved from http://www.sdfm.gov.ua/content/file/Site_docs/2018/20181221/Metod_2_4.pdf

17. Strong Intellectual Methods for Best Alternatives (n.d.). Prohrama SPPR SIMBA DSS. Retrieved from http://simba.su

18. Verkhovna Rada of Ukraine (2017). Про фінансові послуги та державне регулювання ринків фінансових послуг [Pro finansovi posluhy ta derzhavne rehuliuvannia rynkiv finansovykh posluh]. Retrieved from https://zakon.rada.gov.ua/laws/show/2664-14

19. Verkhovna Rada of Ukraine (2017). Про фінансово-кредитні механізми і управління майном при будівництві житла та операціях з нерухомістю [Pro finansovo-kredytni mekhanizmy i upravlinnia mainom pry budivnytstvi zhytla ta operatsiiakh $z$ nerukhomistiu]. Retrieved from https://zakon.rada.gov.ua/laws/show/978-15

20. Verkhovna Rada of Ukraine (2018). Про запобігання та протидію легалізації (відмиванню) доходів, одержаних злочинним шляхом, фінансуванню тероризму та фінансуванню розповсюдження зброї масового знищення [Pro zapobihannia ta protydiiu lehalizatsii (vidmyvanniu) dokhodiv, oderzhanykh zlochynny shliakhom, finansuvanniu teroryzmu ta finansuvanniu rozpovsiudzhennia zbroi masovoho znyshchennia]. Retrieved from https://zakon.rada.gov.ua/laws/show/1702-18

21. Vnukova, N. M., \& Davidenko, D. О. (2015). Свідоцтво про реєстрацію авторського права на твір «Алгоритм вибору найкращого об’єкту інвестування на основі системи підтримки прийняття рішень (СППР) Decision Grid» (25.09.2015, №61854) [Svidotstvo pro reiestratsiiu avtorskoho prava na tvir «Alhorytm vyboru naikrashchoho obiektu investuvannia na osnovi systema pidtrymky pryiniattia rishen (SPPR) Decision Grid» (25.09.2015, №61854)].

22. Xue, Y.-W., \& Zhang, Y.-H. (2016). Research on money laundering risk assessment of customers - based on the empirical research of China. Journal of money laundering control, 19(3), 249-263. https://doi.org/10.1108/JMLC-01-2015-0004

23. Yefymenko, T. I., Hasanov, S. S., \& Korystin, O. Ye. (etc.) (2013). Розвиток національної системи фоінансового моніторингу [Rоzvytok natsionalnoi systemy finansovoho monitorynhu] (380 p.). Kyiv: Akademiia finansovoho upravlinnia. Retrieved from http://afu.kiev.ua/ getfile.php?page_id=450\&num $=13$ 